\title{
MENDIALOGKAN DIMENSI KEILMUAN USHUL FIQH
}

\author{
Oleh:
}

\section{H. A. Yasid 1}

UIN Sunan Ampel Surabaya dan DPK IAI Ibrahimy Situbondo yazidabu@hotmail.com

\begin{abstract}
:
As a method of rational thinking, ushul fiqh not purely built on a foundation of logic, but also based on wahyu. The Ulama did not take the rules of usul fiqh as adapted a formal logic, but they adapt and changing into a new logical thinking which covers the whole essence of religious teachings. The colaboration wahyu and logic that makes ushul fiqh survive alot of time, even attracted the attention of the scientific to be continuously assessed. Epistemologically, usul fiqh is a scientific theory that to see work based on the Islamic arguments law. Ushul fiqh not born in empty space, but is present in accordance challenges and legal needs. The science of fiqh ushul built to formulate rules to get an Istinbath hokum according to the change and development of society.
\end{abstract}

Key words: logika, wahyu, filsafat, epistemologi, istinbath.

\section{A. Pendahuluan}

Dimensi keilmuan ushul fiqh menarik dikaji lantaran memadukan dua unsur penting secara bersamaan, wahyu dan logika. Sebagai sebuah disiplin ilmu yang mempunyai prosedur dan langkah-langkah tertentu, ushul fiqh dibangun selain mengacu pada teks wahyu juga didasarkan pada logika berpikir secara sistematis dan prosedural. Berbeda dengan disiplin ilmu pada umumnya yang hanya mengacu pada salah satu di antara wahyu dan logika, ushul fiqh justru mengapresiasi keduanya secara terintegrasi. Selain pijakan wahyu dalam wujud dalil-dalil kulli, ushul fiqh juga mempunyai basis empirisme ilmu pengetahuan dengan beberapa proses penyederhanaan di dalamnya. Penyederhanaan di sini dianggap perlu karena realitas kehidupan sebagai obyek hukum mempunyai watak begitu kompleks dengan sampel dari berbagai faktor yang terlibat di dalamnya. Dalam konteks inilah ilmu ushul fiqh bertujuan menjembatani keberadaan teks wahyu yang banyak mengungkapkan persoalan secara

${ }^{1}$ Guru Besar bidang Filsafat Hukum Islam dan Direktus Pascasarjana IAI Ibrahimy Sukorejo Situbondo 
global dengan realitas sosial masyarakat yang terus bergerak dinamis.

Penyederhanaan ilmu ushul figh berada pada bagaimana merumuskan ketentuan hukum yang kompatibel dengan realitas masyarakat. Untuk dapat sampai pada tujuan yang ingin dicapai, sebuah ilmu membuat beberpa andaian dan asumsi mengenai obyek-obyek empiris. Asumsi ini perlu karena dapat memberi arah dan landasan bagi kegiatan penelitian dan penelaahan. Sebuah pengetahuan baru dapat dianggap benar secara ilmiah manakala kita bisa menerima asumsi yang dikemukakannya. Semua teori keilmuan mempunyai asumsi-asumsi ini, tidak terkecuali ilmu ushul fiqh, baik yang dinyatakan secara tersurat maupun yang tercakup secara tersirat. Asumsi yang bisa dikemukan dalam ilmu ushul fiqh adalah bahwa pada setiap peristiwa dan kejadian di tengah masyarakat terdapat ketentuan hukumnya. Yang lalu memunculkan persoalan, teks wahyu yang kebanyakan bersifat dhanni (tidak tegas indikasi hukumnya) seringkali memunculkan multi-interpretasi. Kenyataan inilah yang meniscayakan lahirnya teori hukum dan kaidah istinbath sebagai perangkat analisi hukum yang kemudian secara monografis disebut ilmu ushul fiqh.

Dimensi keilmuan ushul fiqh menemukan momentumnya pada era kemunculan madzhab-madzhab besar di abad ke-2 Hijriyyah. Pada era ini tantangan untuk merumuskan kaidah-kaidan istinbath hukum mulai muncul. Dinamika pemikiran hukum saat itu ditandai dengan munculnya kubu tradisionalis (ahl al-hadith) di satu pihak dan kubu rasionalis (ahl al$r a^{\prime} y$ ) di pihak lain. Untuk membingkai konten perdebatan pemikiran kedua kubu di atas kemudian dirasa perlu kehadiran epistemologi ushul fiqh sehingga materi intellectual discourse yang bergulir saat itu bisa diakses serta dikembangkan oleh generasi berikutnya. Pentingnya epistemologi ushul fiqh kian terasa kala itu seiring perkembangan zaman yang semakin pesat, penyebaran Islam yang semakin meluas ke berbagai daerah, serta penetrasi budaya non-arab yang sedikit banyak mempengaruhi keaslian penafsiran terhadap teks wahyu. Dalam kondisi seperti inilah umat Islam memerlukan teori hukum agar para Mujtahid dapat melakukan kegiatan istinbath al-ahkam secara proporsional serta dapat dipertanggungjawabkan secara ilmiah dan akademik.

Di tengah kegelisahan akademik ini, Imam al-Syafi'i (w. $204 \mathrm{H}$ ) kemudian hadir dengan mengusung teori-teori hukum yang dibutuhkan. Dengan bekal pengetahuan yang memadai terhadap eksistensi kedua kubu pemikiran yang saling berhadap-hadapan, al-Syafi'i mencermati betulbetul latar perdebatan yang tengah terjadi. Suguhan berupa teori-teori

14 JURNAL LISAN AL-HAL 
hukum ini tak pelak dapat menurunkan tensi perdebatan antara kubu tradisionalis dan rasionalis. Dengan merujuk pada teori-teori hukum ini maka semua aspek perdebatan dapat dilestarikan secara akademik lantaran satu sama lain saling memahami hakikat kebenaran yang hendak dicapai. Lebih dari itu, generasi penerus dapat melestarikan setiap kali terjadi perdebatan dengan mengacu pada teori-teori hukum tadi. Sejak era inilah epistemologi ushul fiqh menemukan momentumnya untuk kemudian dikembangkan lebih jauh sesuai tuntutan zaman dan peradaban.

Pada perkembangan berikutnya, al-Ghazali (w. 505 H) telah berhasil mengartikulasi ilmu ushul fiqh secara lebih paradigmatis. Persinggungan al-Ghazali dengan perkembangan filsafat pada masanya turut mengondisikan bagaimana ushul fiqh dikerangkakan secara lebih sistematis dan rasioanal dengan tetap menjunjung kaidah-kaidah kebahasaan yang tertuang secara global dalam teks wahyu. Faktor perpaduan antara logika dan wahyu inilah yang mengantarkan ilmu ushul fiqh bisa terus survive dan tak mudah lekang dengan waktu. Gejala kebekuan pemikiran dan stagnasi hukum dalam bentangan sejarahnya hingga saat ini hampir bisa dipastiakan bahwa penyebabnya adalah kurang diberdayakannya ushul fiqh sebagai sebuah epistemologi hukum dalam deretan ilmu keislaman. Dengan belajar pada sejarah ini maka tidak ada alasan yang bisa diterima untuk tidak mengembangkan dan mengaplikasikan ilmu ushul fiqh demi dinamisasi pemikiran hukum Islam pada setiap generasi dan bentangan sejarah.

\section{A. Pembahasan}

\section{Persinggungan Ushul Fiqh dengan Filsafat Yunani}

Dari aspek kesejarahan, pada masa-masa awal Islam filsafat Yunani memang pernah mendominasi kajian. Di Mesir dan Syria, misalnya, bahasa Yunani digunakan sebagai wahana kajian sebelum akhirnya diganti dengan bahasa arab pada abad ke-7 Masehi. Hal itu terjadi ketika Khalifah Abdul Malik bin Marwan dari kerajaan Bani Umayyah memegang kekuasaan di daerah tersebut. Tak pelak lagi, beberapa kota di Mesir seperti Alexandria kemudian menjadi pusat ilmu pengetahuan dan filsafat Yunani. Pada abad itu juga pusat-pusat kebudayaan Yunani merambah ke beberapa kota di Irak. Sebagai bukti sejarah, ketika Islam masuk ke kota Jundishapur, kota yang letaknya tidak jauh dari Baghdad, di sana telah ada akademi dan rumah sakit. Ketika salah seorang raja Bani Abbasiyyah, yaitu al-Manshur, menderita sakait, ia segera diobati oleh kepala rumah sakit 
tersebut, Girgis Ibn Bukhyishu. ${ }^{2}$

Pada masa khalifah Harun al-Rasyid naik tahta pada tahun $786 \mathrm{M}$ buku-buku ilmu pengetahuan Yunani banyak diterjemahkan ke dalam bahasa arab. Bahkan tidak sedikit orang yang sengaja dikirim ke Romawi di Eropa untuk membeli beberapa manuskrip. Pada mulanya penerjemah diutamakan dalam bidang kedokteran, tetapi kemudian ilmu pengetahuan lain dan filsafat pun diterjemahkan. Buku-buku tersebut terlebih dahulu diterjemahkan ke dalam bahasa Siriac, bahasa ilmu pengetahuan di Mesopotamia waktu itu, kemudian baru diterjemahkan ke dalam bahasa Arab. Tapi selang beberapa waktu akhirnya diadakan penerjemahan secara langsung ke dalam bahasa Arab. Di antara para penerjemah yang termasyhur pada waktu itu ialah Hunayn bin Ishaq (w. $873 \mathrm{M})$, seorang Kristiani yang pandai berbahasa Arab dan Yunani, anak Ishaq Hunayn (w. 910 M), Tsabit bin Qurra (w. 890 M) seorang penyembah binatang, Qusta bin Luqa, seorang Kristiani, Hubaisy kemenakan Hunayn, dan Abu Bishr Matta bin Yunus (w. 939 M) yang juga seorang Kristiani. ${ }^{3}$

Melalui kegiatan penerjemahan inilah sebagian besar karya Aristoteles, beberapa karangan Plato serta karangan-karangan mengenai Neo-Platoisme, Galen dan karangan di bidang kedokteran serta ilmu pengetahuan Yunani lainnya dapat dibaca oleh Ulama' dan Cendekiawan Islam. Karangan di bidang filsafat banyak menarik perhatian penganut paham Mu'tazilah sehingga mereka banyak dipengaruhi oleh pemujaan daya akal yang terdapat dalam filsafat Yunani. Tokoh-tokoh Mu'tazilah yang banyak membaca karangan filsafat Yunani antara lain, Abu alHudzail, Ibrahim al-Nadhdham, dan lain-lain. Dalam pembahasan Mu'tazilah mengenai teologi (ilmu kalam), daya akal atau logika yang mereka jumpai dalam filsafat Yunani banyak digunakan. Maka tidak mengherankan bila teologi Mu'tazilah bercorak rasional dan liberal. Di samping itu pun dari kalangan ummat Islam lainnya muncul para Filsuf dan ahli ilmu pengetahuan, terutama di bidang kedokteran seperti Abu alAbbas al-Sarkasyi pada abad ke-9 Masehi, al-Razi pada abad ke-10 Masehi dan lain-lain. Filsuf Islam yang pertama, baru muncul pada abad ke-9 Masehi, yaitu al-Kindi. Belakangan muncul Filsuf berikutnya seperti alRazi, al-Farabi, Ibn Sina (Avecinea), al-Ghazali, Ibn Rusyd (Averoes), dan lain sebagainya. Para Filsuf tersebut kiranya banyak dipengaruhi oleh

2 Juhaya S. Praja, Aliran-aliran Filsafat \& Etika, hlm. 194

${ }^{3}$ Ibid 
Filsuf Yunani, terutama Aristoteles, Plato dan Plotinus. ${ }^{4}$

Pembacaan para Ulama' dan Cendekiawan Islam terhadap filsafat Yunani pada kurun-kurun tersebut amat bersinggungan dengan pengembangan ilmu ushul fiqh yang juga menjunjung unsur logika. Bedanya dengan ilmu-ilmu lain, ushul fiqh tidak murni dibangun atas landasan logika, melainkan juga didasarkan pada wahyu verbal seperti tersirat dalam dalil-dalil kulli ajaran agama. Karena itu, para Juris serta kaum teolog-skolastik Islam saat itu tidak mengadopsi begitu saja logika hellenistik dalam filasafa Yunani. Sebaliknya, mereka melakukan adaptasi dan perubahan terhadap logika Yunani menjadi sebuah logika baru yang mencakup seluruh esensi. Al-Ghazali, misalnya, memasukkan unsur logika dalam mukaddimah masterpiece-nya, al-Mustashfa min 'Ilm al-Ushul. Dalam kata pendahuluan monografi ushul fiqh ini, al-Ghazali menyimplifikasi persoalan logika ke dalam dua sub pembahasan, yaitu alhadd (batasan) dan al-burhan (pembuktian). ${ }^{5}$ Bahkan beliau juga mempunyai karya monografi bertajuk Mi'yar al-'Ilm dan Mahk al-Nadhar yang memuat pembahasaan tentang logika secara lebih luas dan komprehensif. Namun demikian, al-Ghazali akhirnya meninggalkan logika karena dinilainya tidak akan mampu mengantarkan ummat manusia pada nilai-nilai keimanan. Paparan al-Ghazali tentang logika tersebut paling tidak menyiratkan adanya keterkaitan cukup kuat antara logika dan ushul fiqh. Selain mempunyai pijakan wahyu agama, ushul fiqh juga dibangun atas dasar rumus-rumus logika formal.

Hubungan ushul fiqh dengan filsafat Yunani kuno juga dapat dijelaskan dengan pendekatan analisis Abid al-Jabiri. Menurut Pemikir asal Maroko ini, perkembangan pemikiran Islam secara epistemologis meliputi tiga tradisi, yaitu bayani, irfani dan burhani. ${ }^{6}$ Tradisi bayani berkembang paling awal sebelum dunia Islam mengalami kontak budaya secara massif dengan dunia luar. Bahkan ditengarai tradisi ini mulai tumbuh dan berkembang sejak masa Nabi, atau paling tidak pada era pembesar Sahabat. Hal ini dapat ditandai dengan munculnya tradisi interpretasi terhadap teks wahyu dan sistematisasi sastra arab dalam bentuk antologi (diwan al-'arab) yang diprakarsai oleh Ibnu 'Abbas (w. 68 H). Secara garis besar, tradisi ini dapat dipilah menjadi dua fase. Pertama, fase interpretasi teks seperti dipaparkan di atas, sementara yang kedua adalah fase produktivitas sastra arab yang kelahirannya dibarengi oleh

\footnotetext{
${ }^{4}$ Ibid, hlm. 194 - 195

${ }^{5}$ Al-Ghazali, al-Mustashfa min 'Ilm al-Ushul, Juz I, hlm. 21 - 58.

${ }^{6}$ Muhammad 'Abid al-Jabiri, Bunyah al-'Aql al-'Arabi, hlm. 9.
} 
munculnya firqah-firqah politik maupun aliran-aliran paham dalam ilmu kalam pasca peristiwa al-tahkim antara Ali bin Abi Thalib dan Mu'awiyah. ${ }^{7}$

Tradisi bayani menemukan momentumnya ketika mampu membentuk epistemologi ilmu dalam kerangka teori ushul (pokok) dan furu' (cabang). Selain itu, tradisi ini juga telah menciptakan suasana keberagamaan yang lebih rasional selain juga menelorkan produk intelektual ilmu kebahasaan dan keagamaan. Dalam konteks ini, al-Syafi'i (w. $204 \mathrm{H}$ ) dinilai sebagai salah satu peletak teori formulasi tradisi bayani. Sumbangan penting al-Syafi'i dalam proses formulasi epistemologi bayani adalah pemikiran ushul fiqh sebagai metode artikulasi, sebagaimana dituangkan dalam masterpiece-nya al-risalah. Al-Syafi'i telah berjasa mengangkat reputasi assunnah pada posisi kedua dan berfungsi tasyri setelah Alqur'an. Secara lebih detail al-Syafi'i membagi tradisi bayani pada lima kategori, yaitu;

a. Bayan (penjelasan) yang tidak memerlukan penejelasan lain, seperti sejumlah teks Alqur'an yang tidak multi-interpretasi.

b. Bayan yang mempunysi bagian yang mujmal (global) dan memerlukan penjelasan dari Assunnah.

c. Bayan yang secara keseluruhan bersifat mujmal sehingga memerlukan penjelasan Assunnah.

d. Bayan assunnah, yakni substansi Assunnah yang sesungguhnya merupakan penjelasan wahyu Tuhan dan mutlak harus diapresiasi sesuai petunjuk Alqur'an.

e. Bayan al-Ijtihad yang dismplifikasi menjadi aktivitas qiyas (analogi). ${ }^{8}$

Dalam epistemologi bayani, posisi teks sedemikian sentral sehingga aktivitas intelektual senantiasa berada dalam wilayah dan lingkarannya serta berorientasi pada reproduksi teks secara lebih luas. Peradaban Islam yang berkembang pada fase ini bisa disebut peradaban teks. Begitu pentingnya posisi teks sehingga mampu mengembangkan dasar-dasar peradaban dan ilmu pengetahuan. Namun demikian, bukanlah independensi teks yang dapat mengkrangkakan lahirnya sebuah epistemologi. Sebaliknya, kerangka budaya dan pantulan ilmu hanya bisa timbul melalui pergulatan panjang ummat manusia dengan realitas sosialnya. Teks dalam kaitan ini memiliki pemaknaan luas menyangkut sesuatu yang terintegrasi dengan konteks pengalaman sejarah ummat

${ }^{7}$ Ibid, hlm. 20.

${ }^{8}$ Ibid, hlm. 22 - 23; al-Syafi'i, al-Risalah, hlm. 505. 
manusia. ${ }^{9}$

Setelah dunia Islam mengalami kontak massif dengan budaya luar dan mengintrodusir khazanah ilmu-ilmu klasik maka nalar pun mulai berkembang dalam diskursus intelektual Islam dan kemudian melahirkan epistemologi irfani. Nalar irfani bertumpu pada al-hikmah al-isyraqiyyah (pengetahuan yang memancar). Menurut epistemologi ini, sistem istidlal yang mengedepankan nalar tidak akan mampu menerima pengetahuan dari sumber aslinya (Tuhan). Sebaliknya, ilmu pengetahuan dapat diperoleh melalui intuisi yang telah mengalami kondisi kasyf (terbukanya tirai penghalang) dan isyraq (terpancarnya sinar). ${ }^{10}$ Secara hierarkhis, jenis pengetahuan semacam ini dianggap berada pada posisi paling tinggi lantaran menyatu dengan hati dan intuisi. Prasyarat untuk memperoleh pengetahuan ini pun amat bergantung pada tingkat kesungguhan, ketulusan dan keistkamahan seseorang. Jika epistemologi bayani dapat diraih oleh seorang sastrawan atau juris yang tekun dan tulus, maka epistemologi irfani hanya bisa disentuh oleh mereka yang mencapai derajat wilayah (kewalian). Orang-orang suci yang telah mencapai derajat ini diyakini memiliki indra mukasyafah sehingga sesuatu yang abstrak bagi kebanyakan orang, bisa terlihat jelas bagi mereka. ${ }^{11}$

Tidak seperti epistemologi bayani dan irfani yang datang bersamaan dan lebih awal sejak masa-masa awal Islam, epistemologi burhani datang kemudian berbarengan dengan masuknya pengaruh filsafat Yunani kuno ke dalam tradisi pemikiran Islam. Tradisi burhani bertumpu sepenuhnya pada perangkat kemampuan intelektual dan daya rasional untuk pemerolehan pengetahuan. Pengaruh yang ditimbulkan oleh masuknya pemikiran Yunani adalah introduksi nalar universal yang kemudian menjadi basis utama epistemologi burhani. Jika bangunan metodologi bayani dan irfani sangat mengapresiasi teks maka tidak demikian halnya dalam tradisi burhani. Konstruk metodologi burhani sangat deduktif dan independen mengedepankan nalar universal untuk menggapai ilmu pengetahuan yang diyakini benar. ${ }^{12}$

Dari jabaran epistemologi bayani, irfani dan burhani tersebut maka kombinasi teks, nalar dan intuisi sangat mewarani pembentukan struktur ilmu pengetahuan dalam Islam. Ushul fiqh lahir dalam kondisi psikologis yang sangat dialektif dan interaktif seperti itu. Bangunan ushul fiqh yang

\footnotetext{
${ }^{9}$ Nashr Hamid Abu Zayd, Mafhum al-Nash: Dirasah fi Ulum al-Qur'an, hlm. 11.

${ }^{10}$ Muhammad 'Abid al-Jabiri, Bunyah al-'Aql al-'Arabi, hlm. 252.

11 Ibid, hlm. 251.

12 Ibid, hlm. $415-416$.
} 
mula-mula dikreasi pada tradisi bayani yang sangat mengapresiasi teks tidak bisa dipisahkan begitu saja dengan tradisi burhani yang kemudian membentuk filsafat skolastik kalam atas pengaruh pemikiran Yunani. Begitu dekatnya tradisi bayani dan burhani dalam ilmu ushul fiqh sampaisampai pola deduktif ushul fiqh yang dibangun al-Syafi'i sangat populer dengan sebutan aliran mutakallimin lantaran penyusunannya mengadopsi pola yang biasa dilakukan kalangan filsafat kalam.

Ushul fiqh juga mempunyai kedekatan nasab dengan tradisi irfani yang mengedepankan intuisi secara sufistik. Penggunaan ushul fiqh dalam upaya merumuskan hukum-hukum operasioanal mesti dilandaskan pada nilai-nilai sufisme atau etika-moral sesuai prinsip dalam tujuan tasyri', yakni untuk menebar kemaslahatan. Karenanya, dalam tradisi pemikiran jurisprudensi Islam, hukum dan moral dibangun secara integral dan tidak bisa dipisah-pisahkan satu sama lain. Hukum tanpa moral bisa mengarah pada tirani, sementara moral saja tanpa dibingkai dengan postulat hukum bisa disebut utopia. Pandangan seperti ini berbeda dengan aliran filsafat hukum positivistik yang memosisikan ketentuan hukum dan moralitas sebagai dua hal yang berdiri sendiri dan tidak memiliki keterkaitan satu sama lainnya.

\section{Wahyu dan Logika sebagai Pijakan Ushul Fiqh}

Ushul fiqh selain mempunyai pijakan wahyu juga didasarkan pada dalil-dalil logis-empiris dalam rangka memunculkan berbagai ketentuan hukum operasional. Dengan ungkapan lain, dalam proses pembentukannya menjadi sebuah epistemologi, ushul fiqh memadukan unsur teks normatif berupa wahyu verbal di satu pihak dan logika formal di pihak lain. Wahyu yang dimaksudkan sebagai dasar pijakan ilmu ushul fiqh adalah berupa teks Alqur'an maupun hadis yang memuat aturanaturan hukum secara garis besar (kulli) dan global (ijmali). Dari hukumhukum kulli-ijmali ini kemudian para Juris (Mujtahid) perlu merumuskan kaidah-kaidah pengambilan kesimpulan hukum (istinbath) untuk menelorkan hukum-hukum operasional yang sesuai dengan semangat teks wahyu untuk mengimplementasikan prinsip dan tujuan tasyri', yakni untuk menebar kemaslahatan baik di dunia maupun di akhirat.

Para Juris memerlukan dalil logika selain dalil wahyu dalam upaya merumuskan kaidah-kaidah istinbath al-ahkam. Logika yang dimaksud adalah untuk menyusun kriteria bagaimana mengevaluasi suatu argumen yang benar. Logika dengan pengertian ini, mempelajari metode-metode dan prinsip-prinsip yang dipergunakan untuk membedakan penalaran

$20 \mid$ JURNAL LISAN AL-HAL 
yang lurus dan penalaran yang menyimpang. Logika berhubungan dengan kegiatan berpikir, tetapi bukan sekedar berpikir sebagaimana kodrat rasional yang dimiliki manusia. Dalam membahas jalan pikiran, logika selalu mendasarkan aktivitasnya pada patokan hukum-hukum pemikiran sehingga dapat menghindarkan orang dari kesalahan dan kesesatan. Dalam konteks inilah logika disebut juga sebagai ilmu pengetahuan. Ilmu ushul fiqh selain didasarkan pada wahyu verbal juga mempunyai dasar pijakan logika seperti dalam pengertian ini.

Komposisi berimbang antara unsur wahyu dan logika dalam anatomi ushul fiqh memunculkan apresiasi dari banyak kalangan. Mereka menganggap bahwa ilmu ushul fiqh merupakan falsafah Islam faktual yang berfungsi mengawasi kehidupan manusia sebagai khalifah yang senantiasa beraktivitas di muka bumi. Tujuannya adalah agar manusia tidak menyimpang yang menyebabkan mereka bisa terseret dan terjerumus ke dalam berbagai ketimpangan, kehilangan fitrah, dan kebingungan akal ketika berhadapan dengan sejumlah pendapat dan ijtihad yang membutuhkan aturan hukum secara mengikat. Atas dasar ini, ilmu ushul fiqh merupakan sebuah epistemologi hukum sangat penting yang dihasilkan oleh peradaban Islam. ${ }^{13}$

Kombinasi wahyu dan logika sebagai dasar pijakan ushul fiqh juga pernah diapresiasi Imam al-Ghazali (w. 1111 M) dalam karyanya alMustashfa min 'Ilm al-Ushul. Ulama' Ushuli dari kalangan Syafi'iyyah (Mutakallimin) ini membagi ilmu pengetahuan menjadi tiga bagian. Pertama: 'aqli mahdl (nalar murni), yaitu ilmu pengetahuan yang sematamata dilandaskan pada akal manusia tanpa dasar pijakan wahyu, seperti ilmu matematika, ilmu tehnik, ilmu astronomi dan lain-lain. Kedua: naqli mahdl (wahyu murni), yakni ilmu pengetahuan yang bertumpu pada teksteks wahyu tanpa ada intervensi nalar, seperti ilmu tafsir, ilmu hadis dan lain-lain. Ketiga: izdiwaji (gabungan logika dan wahyu), yaitu ilmu pengetahuan yang dasar pijakannya adalah wahyu dan nalar secara bersamaan dan berimbang. Ilmu fiqh dan ushul fiqh menurut al-Ghazali termasuk dalam kategori ketiga ini dan beliau menggolongkannya dalam level ilmu paling tinggi. ${ }^{14}$

Apresiasi al-Ghazali ini tidaklah berlebihan lantaran Ilmu ushul fiqh telah menorehkan sejarahnya melalui perjalanan panjang yang cukup mengesankan dalam penentuan arah dan dinamika perubahan masyarakat. Ilmu ini juga telah memberikan corak yang jelas bagi

${ }^{13}$ Abdul Halim Uways, al-Fiqh al-Islami Bayna al-Tathawwur wa al-Thabat, hlm. 160.

${ }^{14}$ Ghazali, al-Mustashfa min 'Ilm al-Ushul, Juz I, hlm. 13 - 14 
peradaban Islam dalam berbagai aspek kehidupan. Telah banyak pemikiran besar yang mencoba menggali sejumlah aturan dan kaidah fiqh dari berbagai teks wahyu. Para Juris Islam yang dikomandani oleh Imam al-Syafi'i telah berupaya mengukuhkan ilmu ushul fiqh baik secara partikular maupun universal sehingga ummat merasa yakin bahwa tidak ada satu celah pun yang tidak tersentuh oleh ilmu ini. ${ }^{15}$

Di balik apresiasi terhadap keberadaan ushul fiqh, bukan berarti tidak ada kalangan yang hendak menggugat dilakukannya pembaharuan terhadap bangunan ilmu ini sebagai sebuah metodologi hukum yang sudah sedemikian establish. Hasan Turabi, Pemikir Islam dari Sudan, menyerukan dilakukannya reformasi ushul fiqh. Turabi pada dasarnya dapat mengakui kegemilangan ushul fiqh klasik yang telah dibangun secara susah payah oleh Ulama' terdahulu. Akan tetapi seiring dengan mundurnya kehidupan beragama belakangan ini maka praktis ummat Islam tidak mampu menelorkan fiqh baru yang cemerlang setelah fiqh menjadi sebuah disiplin ilmu. Dari kenyataan ini Turabi menengarai adanya kejumudan ushul fiqh sehingga perlu ada langkah-langkah pembaharuan. ${ }^{16}$

Untuk meyakinkan gagasannya ini, Hasan Turabi mengemukakan contoh yang dikembangkan Imam Ibnu Hazm tentang konsep istishhab. Walaupun Ibnu Hazm termasuk salah seorang penganut madzhab skriptualis dzahiriyyah, namun ia mampu membuka pintu perkembangan fiqh. Ibnu Hazm mempunyai perhatian cukup luas dalam masalah politik, hukum, dan persoalan-persoalan sosial kemasyarakatan. Kasus-kasus seperti inilah yang sesungguhnya banyak dihadapi ummat Islam sekarang ketimbang kasus-kasus lain yang bersifat khusus. Aspek kehidupan ummat memerlukan ijtihad yang amat luas dan memerlukan kesungguhan intelektual di dalam upaya memberikan penekanan yang kuat pada aspekaspek tersebut dan pada sejumlah kaidah ushul fiqh yang relevan. ${ }^{17}$

Bagi Turabi, terbatasnya jumlah teks memunculkan persoalan tersendiri dalam upaya pengembangan hukum. Dalam beragam persoalan yang bersifat umum kita mesti merujuk pada teks-teks wahyu yang ada melalui sejumlah kaidah penafsiran yang mendasar. Namun demikian, pendekatan seperti ini saja belumlah cukup lantaran sedikitnya jumlah teks wahyu. Karena itu, kita perlu mengembangkan metode ijtihad yang

${ }^{15}$ Abdul Halim Uways, al-Fiqh al-Islami Bayna al-Tathawwur wa al-Thabat, hlm. 161.

${ }^{16}$ Ibid, hlm. 150

17 Ibid.

22 JURNAL LISAN AL-HAL 
akan memperluas pandangan yang dibangun di atas fondasi teks-teks yang jumlahnya sangat terbatas tadi. Dalam konteks ini, Turabi menawarkan penggunaan qiyas untuk mengembangkan teks dan memperluas materinya. Menurutnya, qiyas merupakan dimensi paling luas dalam ijtihad. ${ }^{18}$ Penilaian seperti ini sesungguhnya pernah dilakukan oleh alSyafi'i dua abad belas silam. Dalam masterpiece-nya, al-Risalah, al-Syafi'i menyimplifikasi persoalan ijtihad yang mempunyai cakupan sangat luas dengan qiyas. Artinya, menurut beliau qiyas itu identik dengan seluruh aktivitas ijtihad dalam rangka menelorkan hukum-hukum operasional. ${ }^{19}$

Masih menurut Turabi, qiyas yang dikembangkan selama ini sangat sempit cakupannya. Kondisi seperti ini perlu mendapatkan perhatian sehingga kita bisa mempolanya serta menjadikannya sebagai sebagian dari sarana kebangkitan fiqh. Penegrtian qiyas sesungguhnya amat luas mencakup makna signifikansi spontan dengan persoalan sebelumnya. Selain itu, ia juga mencakup makna teknis yang dibuat oleh para Juris untuk menyandarkan hukum asal pada hukum turunannya. Hal ini dilakukan dengan mengompromikan illat hukum yang baku kepada hal lain yang mereka syaratkan di dalam pokok dan cabangnya serta objek hukumnya. Ini adalah bagian dari qiyas yang mencakup kasus-kasus baru yang dinisbatkan pada kasus-kasus lama yang jelas dan telah ditetapkan hukumnya melalui teks wahyu. ${ }^{20}$

Para Juris Islam atau Fuqaha' dengan pendekataan seperti ini dapat menentukan hukum pada beberapa kasus yang benar-benar baru. Seperti inilah gambaran qiyas terbatas yang barangkali penafsirannya perlu disempurnakan sehingga dapat menjangkau aneka perkembangan yang terus terjadi. Bidang yang luas dalam agama hampir tidak ditemukan pola penyelesaiannya kecuali melalui qiyas alami yang bebas dari sejumlah persyaratan yang mengikat yang sesungguhnya hal tersebut dibuat oleh para Filsuf Yunani dan kemudian dinukil oleh para Juris Islam. ${ }^{21}$

Untuk melandingkan gagasan pembaharuan ilmu ushul fiqh ini Turabi menyusun sebuah buku monografi bertajuk tajdidu 'ilmi ushul alfiqh (Pembaharuan Ilmu Ushul Fiqh). Namun jika dicermati lebih dalam, seruan tersebut sesungguhnya kurang menyentuh esensi persoalan. Sebab pembaharuan atau reformasi menuntut adanya tawaran kaidah-kaidah baru sebagai wujud perbaikan dari kaidah-kaidah yang sudah melembaga

18 Ibid, hlm. 152.

${ }^{19}$ Lihat al-Syafi'i, al-Risalah, hlm. 505.

${ }^{20}$ Abdul Halim Uways, al-Fiqh al-Islami Bayna al-Tathawwur wa al-Thabat, hlm. 153.

21 Ibid. 
selama ini. Hal ini belum nampak tersuguhkan secara elaboratif dalam seruannya tersebut. Apa yang dilakukan Turabi sebenarnya seruan moral untuk mengoptimalkan penggunaan ushul fiqh untuk mereformasi bangunan fiqh yang sesuai dengan perkembangan. Atau dengan ungkapan lain, apa yang dilakukan Turabi adalah bagaimana pengembangan ilmu ushul fiqh bisa dilakukan baik dari segi teknis maupun materinya. Dengan pola pengembagan seperti ini maka bangunan ushul fiqh yang sudah melembaga sesungguhnya masih bisa kita pertahankan dengan mengaplikasikannya sesuai persoalan-persoalan kontemporer yang dihadapi ummat belakangan ini. Pada kenyataannya, upaya pembaharuan apa pun yang dilakukan ujung-ujungnya juga tidak keluar dari lingkup bangunan ushul fiqh yang telah dirumuskan sebelumnya.

Apa yang menjadi seruan Turabi sesungguhnya sama dengan persepsi kebanyakan para Juris akhir-akhir ini menyangkut kurang difungsikannya ilmu ushul fiqh untuk menorehkan ketentuan-ketentuan hukum baru sesuai tingkat perkembangan masyarakat. Keprihatinan seperti ini juga dilatari cara pandang sebagian besar masyarakat terhadap disiplin ilmu ushul fiqh. Mereka mengapresiasi ilmu ushul fiqh sebatas sebagai warisan yang mesti dipelajari dalam bentuknya yang bersih dan murni. Selain itu, keterbatasan metode pengajaran dan kesulitan bahasa yang terdapat pada sebagian sumber-sumber primer ilmu ushul fiqh turut mengondisikan problem pemberdayaan ilmu ini di tengah kehidupan beragama. Karena itu, jika kita menginginkan ilmu ini berkembang pesat secara alami dalam kehidupan beragama maka kita mesti mengubah cara pandang kita terhadap disiplin ilmu ini selain juga harus mengembangkan metode kajian dan pengajaran sesuai konteks perkembangan teknologi informasi dan komunikasi.

Jika dicermati lebih mendalam, kaidah-kaidah ushul fiqh yang ada sesungguhnya diadopsi dari nilai-nilai universal ajaran agama, bukan dari aspek partikulasi ajaran yang sangat teknis dan bersifat juz'i. Dengan mengacu pada nilai-nilai universal atau dalil kulli seperti ini maka ushul fiqh tidak mudah ketinggalan zaman dalam menyikapi aneka persoalan yang terus berkembang. Faktor lain yang menyebabkan ilmu ushul fiqh mampu beradaptasi dengan perubahan adalah keterlibatan logika formal dalam perumusan kaidah-kaidah-nya. Begitu rasionalnya bangunan kaidah ushul fiqh sampai-sampai banyak kalangan yang berestimasi bahwa disiplin ilmu ini sebenarnya merupakan produk impor dari ancient greek (Filsafat Yunani Kuno).

Dalam batas tertentu, Turabi termasuk pemikir yang mempunyai

24 JURNAL LISAN AL-HAL 
anggapan demikian. Menurutnya, persoalan ushul fiqh semisal qiyas, istihsan, mashlahah mursalah, istishhab, dan lain-lain merupakan prinsipprinsip yang berasal dari filsafat Yunani dan logika ilmiah. Jika semua itu dapat berubah maka demikian pula dengan ushul fiqh. Apabila prinsipprinsip logika Yunani mengalami perkembangan sebagaimana metodologi ilmu alam dan ilmu sosial maka ummat Islam mesti pula menggunakan prinsip-prinsip tersebut dalam ijtihad. Dengan pendekatan seperti ini maka upaya pembaharuan ushul fiqh dapat dilakukan. ${ }^{22}$

Gagasan seperti ini juga mempunyai kelemahan akademik karena seolah-olah Islam tidak mempunyai metodologi ilmiah sama sekali. Keterlibatan logika ilmiah seperti terperagakan dalam filsafat Yunani memang tidak dapat dipungkiri terjadi dalam rumusan kaidah-kaidah ilmu ushul fiqh. Namun untuk mengatakan ilmu ushul fiqh sepenuhnya produk impor dari ancient greek juga kurang proporsional. Sebab, logika ilmiah yang diperagakan dalam ilmu ushul fiqh dilandaskan pada esensi ajaran wahyu secara universal selain juga mengapresiasi logika ketika hendak menghubungkan teks dengan indikasi hukumnya. Dari perpaduan inilah kemudian lahir rumus-rumus dan metodologi ilmiah dalam Islam yang kemudian membentuk epistemologi ushul fiqh.

\section{Ushul Fiqh sebagai Ilmu, Bukan Pengetahuan}

Kata 'ilmu' dalam bahasa arab disebut 'ilm dan dalam bahasa inggris bisa diterjemahkan menjadi science. ${ }^{23}$ Sedangkan kata pengetahuan dalam bahasa arab bisa diterjemahkan menjadi ma'rifah dan dalam bahasa inggris biasa disebut knowledge. ${ }^{24}$ Dengan pemetaan bahasa seperti ini maka jelas bahwa ilmu dan pengetahuan sesungguhnya merupakan dua hal berbeda, walaupun dalam pengungkapan sehari-hari kata ilmu sering dipadankan dengan pengetahuan menjadi 'ilmu pengetahuan'.

Pengetahuan merupakan produk kegiatan berpikir sehingga manusia dapat menemukan dirinya dan menghayati hidup dengan lebih sempurna. Pengetahuan dengan pemaknaannya ini mempunyai cakupan lebih luas ketimbang ilmu. Ilmu tak lain merupakan kumpulan pengetahuan yang dibatasi oleh ciri-ciri tertentu yang dapat membedakan ilmu dari pengetahuan-pengetahuan lainnya. ${ }^{25}$ Atau dengan ungkapan

22 Ibid, hlm. 156.

${ }^{23}$ Rohi al-Ba'albaki, al-Mawrid Qamus 'Arabi-Inglizi, hlm. 775.

${ }^{24} \mathrm{Ibid}, \mathrm{hlm} .1070$.

25 Jujun S. Suriasumantri, Ilmu dalam Perspektif, hlm. 4. 
lain, ilmu adalah pengetahuan yang sistematis dan dengan sadar menuntut kebenaran. ${ }^{26}$ Tidak seperi pengetahuan yang berwatak umum, ilmu mempunyai ciri, tahapan dan metode tertentu. Ilmu bukan merupakan tujuan, melainkan proses dan tahapan untuk menggapai sebuah tujuan itu sendiri. Rangkaian proses tersebut terikat oleh jalinan hubungan logis yang secara deduktif dapat dijabarkan menjadi langkah-langkah tertentu. Dalam kaitan ini, ushul fiqh merupakan metode dan langkah-langkah tertentu yang harus dilalui dalam rangkaian proses penggalian hukum (istinbath al-ahkam).

Ciri-ciri keilmuan didasarkan pada jawaban yang diberikan ilmu terhadap beberapa pertanyaan pokok, yaitu: 1) apakah yang ingin kita ketahui; 2) bagaimana cara kita memperoleh pengetahuan; 3) apakah nilai pengetahuan tersebut bagi kita. Ilmu merupakan salah satu dari buah pemikiran manusia dalam menjawab pertanyaan-pertanyaan ini. Ilmu meerupakan salah satu dari pengetahuan manusia. Untuk dapat menghargai ilmu sebagaimana mestinya sesungguhnya kita harus mengerti apakah hakekat ilmu itu sendiri. Berbagai buah pemikiran besar sebenarnya merupakan serangkaian jawaban yang diberikan atas ketiga pertanyaan tadi. Pemikiran-pemikiran besar dalam sejarah kebudayaan manusia dapat dicirikan dan dibedakan dari cara mereka menjawab pertanyaan-pertanyaan itu. ${ }^{27}$

Pada kenyataannya ilmu telah membentuk peradaban manusia dalam bentangan sejarahnya. Namun demikian, kebenaran yang ditorehkan ilmu pengethuan bukanlah kebenaran mutlak dan satusatunya. Sebaliknya, masih terdapat banyak sumber kebenaran lain yang dapat memperkaya khazanah kehidupan ummat manusia. Semua kebenaran dengan bereneka ragam sumbernya ini mengandung kemanfaatan bilamana diletakkan pada konteknya yang tepat dan layak. Kehidupan manusia terlalu rumit dianaalisis hanya oleh satu jalan pemikiran. Sebaliknya, ia bisa dijabarkan melalui ragam pendekatan selain ilmu, misalnya agama, filsafat, seni dan lain sebagainya. Semua ini saling berkolaborasi dan saling membutuhkan. Atas dasar ini Ilmuwan Albert Einstein pernah mengatakan bahwa ilmu tanpa agama adalah buta dan agama tanpa ilmu adalah lumpuh. ${ }^{28}$

Kembali pada pertanyaan pokok tentang apa yang ingin kita

${ }^{26}$ Juhaya S. Praja, Aliran-aliran Filsafat \& Etika, hlm. 11.

${ }^{27}$ Jujun S. Suriasumantri, Ilmu dalam Perspektif, hlm. 2 - 3.

${ }^{28}$ Ibid, hlm. 3 - 4.

26 JURNAL LISAN AL-HAL 
ketahui, ontologi-lah yang membahas persoalan ini. Kemudian, bagaimana cara kita mendapatkan pengetahuan, kita mesti berpaling pada epistemologi. Sedangkan pertanyaan menyangkut nilai kegunaan pengetahuan yang hendak diperoleh, kita mesti menggunakan pendekatan aksiologi. Dengan pemetaan seperti ini maka setiap bentuk pemikiran manusia dapat dikembalikan pada dasar-dasar ontologi, epistemologi dan aksiologi.

\section{Dasar Ontologi Ilmu}

Untuk menjawab pertanyaan apa yang ingin kita ketahui, tentunya tidak semua pengetahuan dapat kita peroleh dan kita jabarkan. Ontologi ilmu membatasi diri pada peristiwa dan kejadian yang bersifat empiris. Faktanya, kebanyakan orang dapat memperoleh pengetahuan dari pengalaman yang diperoleh melalui indera yang dimiliki. ${ }^{29}$ Fakta empiris adalah fakta yang dapat dialami langsung oleh manusia dengan menggunakan panca inderanya. Ruang lingkup kemampuan panca indera manusia dan peralatan yang dikembangkan sebagai pembantunya membentuk apa yang dikenal dengan dunia empiris. Obyek penelaahan ilmu mencakup seluruh aspek kehidupan yang dapat diuji oleh panca indera manusia. Ilmu mempelajari berbagai gejala dan peristiwa yang menurut anggapannya mempunyai manfaat bagi kehidupan manusia. berdasarkan obyek yang ditelaahnya, ilmu dapat disebut sebagai pengetahuan empiris di mana obyek-obyek yang berbeda di luar jangkauan manusia tidak termasak ke dalam bidang penelaahan keilmuan tersebut. ${ }^{30}$

Dasar ontologi ilmu seperti ini tentunya berbeda dengan agama atau bentuk-bentuk pengetahuan lainnya. Jika yang menjadi dasar pijakan ilmu adalah pengalaman empirik maka dalam agama hal yang menjadi pokok sebagai dasar pijakan adalah kepercayaan (iman). Tidak dapat dipungkiri bahwa anjuran menggunakan nalar dan logika seringkali kita temukan dalam lemabaran teks agama. Namun demikian kebenaran agama yang mempunyai nilai absolut tetap berbeda dengan kebenaran ilmiah yang bersifat nisbi. Karena itu, selain anjuran menggunakan nalar dan logika yang mempunyai perspektif ilmu pengetahuan tersebut, tidak jarang ajaran agama mengungkapkan persoalan yang abstrak dan belum pernah teruji secara empiris. Sebut saja sebagai misal, keberadaan surga, neraka, reinkarnasi, serta kisah-kisah kaum masa lampau maupun yang

${ }^{29}$ Juhaya S. Praja, Aliran-aliran Filsafat \& Etika, hlm. 10

30 Jujun S. Suriasumantri, Ilmu dalam Perspektif, hlm. 6 
masih akan datang dan akan terjadi di kemudian hari. Intinya, betapa pun agama mempunyai dimensi ilmu seperti dijabarkan dalam ayat-ayat kauniyyah-nya, akan tetapi tidak seluruhnya dapat diakses dengan prosedur pengetahuan. Yang menjadi dominan dalam struktur ajaran agama tetaplah kepercayaan dan keimanan terhadap dzat pencipta beserta seluruh perangkat ajaran yang diturunkan melalui para RasulNYA.

Ontologi ilmu juga berbeda dengan filsafat walaupun keduanya mempunyai hubungan sangat erat. Dikatakan mempunyai hubungan dekat karena dengan modal empirik yang dimiliki, ilmu membekali filsafat dengan bahan-bahan yang deskriptif dan faktual yang sangat penting. Setiap filsuf dalam bentangan sejarahnya condong untuk mengembangkan pandangan ilmiahnya. Sebaliknya, ilmu melakukan pengecekan terhadap filsafat dengan menghilangkan ide-ide yang tidak sesuai dengan pengetahuan ilmiah. Bedanya, ilmu-ilmu tertentu pada umumnya menyelidiki bidang-bidang yang terbatas, sementara filsafat mencoba melayani seluruh kepentingan manusia. Dengan demikian, filsafat lebih bersifat inklusif ketimbang ilmu karena ia selalu berusaha untuk mendapatkan pandangan yang lebih komprehensif tentang hakekat sesuatu.

Jika ilmu dalam pendekatannya lebih analitis dan deskriptif maka filsafat lebih sintetik dan sinoptik dalam menghadapi hakekat kehidupan. Ilmu berusaha untuk menganalisis seluruh unsur yang menjadi bagianbagian dan anggotanya, sedangkan filsafat berusaha untuk mengembangkan sintesa hasil interpretasi untuk menemukan makna hakiki. Jika ilmu berusaha untuk menghilangkan faktor-faktor pribadi dan menganggap sepi nilai-nilai demi menghasilkan obyektivitas, maka filsafat lebih mementingkan personalitas dan nilai-nilai. Ilmu menggunakan pengamatan, eksprimen, dan pengalaman inderawi, sedangkan filsafat berusaha menghubungkan penemuan-penemuan ilmu dengan maksud menemukan hakikat kebenarannya. ${ }^{31}$

Dengan basis empiris yang dimiliki, ilmu sesungguhnya merupakan abstrak yang disederhanakan dari rangkaian pengalaman manusia. Penyederhanaan seperti ini dianggap perlu karena fakta kejadian alam yang begitu kompleks dengan sampel dari berbagai faktor yang terlibat di dalamnya. Namun demikian, ilmu tidak bermaksud memotret dan memproduksi suatu kejadian tertentu lalu mengabstarakkannya begitu saja dalam bahasa keilmuan. Sebaliknya, ilmu bertujuan untuk mengerti

${ }^{31}$ Juhaya S. Praja, Aliran-aliran Filsafat \& Etika, hlm.13 - 14. 
mengapa hal itu terjadi dengan membatasi diri pada hal-hal yang asasi. Dengan ungkapan lain, proses keilmuan bertujuan untuk memeras hakekat obyek empiris tertentu untuk mendapatkan sari berupa pengetahuan mengenai obyek tertentu. Untuk mendapatkan pengetahuan ini ilmu membuat beberpa andaian dan asumsi mengenai obyek-obyek empiris. Asumsi ini perlu karena dapat memberi arah dan landasan bagi kegiatan penelaahan. Sebuah pengetahuan baru dapat dianggap benar manakala kita bisa menerima asumsi yang dikemukakannya. Semua teori keilmuan mempunyai asumsi-asumsi ini, baik yang dinyatakan secara tersurat maupun yang tercakup secara tersirat. ${ }^{32}$

Dalam konteks ushul fiqh, penyederhanaan ilmu berada pada bagaimana merumuskan ketentuan hukum yang kompatibel dengan realitas masyarakat. Asumsi yang bisa dikemukan adalah bahwa pada setiap peristiwa dan kejadian di tengah masyarakat terdapat ketentuan hukumnya. Yang lalu memunculkan persoalan, teks agama kebanyakan mengungkapkan ketentuan secara global dan garis besar. Kenyataan inilah yang meniscayakan lahirnya teori hukum dan kaidah istinbath yang kemudian secara monografis disebut ilmu ushul fiqh. Pertanyaan ontologis yang bisa dikemukakan, apakah ketentuan hukum sudah ada sebelum para Juris atau Mujtahid melakukan kerja istinbath-nya? Jika jawabannya iya maka ketika terjadi diferensiasi pendapat hukum di anatara para Juris, yang memilki bobot kebenaran hanyalah satu yang sedia kala ada tersebut. Dalam kondisi seperti ini teori pluralisme hukum tidak dapat diterapkan lantaran wujud hukum bersifat tunggal. Sebaliknya, jika entitas hukum baru ada di saat terjadi aktivitas ijtihad maka semua perbedaan pendapat hukum yang sering mengemuka di anata para Mujtahid mempunyai bobot kebenaran yang merata dan saat inilah teori pluralisme hukum bisa diterapkan.

\section{Dasar Epistemologi Ilmu}

Epistemologi adalah teori pengetahuan yang membahas secara mendalam segenap proses yang terlihat dalam usaha kita untuk memperoleh pengetahuan. Ilmu merupakan pengetahuan yang didapat melalui proses tertentu yang dinamakan metode keilmuan. Metode inilah yang membedakan ilmu dengan buah pemikiran yang lainnya. Dengan perangkat metode yang dimiliki ilmu lebih merupakan kegiatan daripada sekedar produk yang siap dikonsumsikan. Kata sifat "keilmuan" lebih mencerminkan hakekat ilmu daripada istilah ilmu sebagai kata benda.

${ }^{32}$ Jujun S. Suriasumantri, Ilmu dalam Perspektif, hlm. 6 
Kegiatan dalam mencari pengetahuan tentang apa pun selama hal itu terbatas pada obyek empiris dan pengetahuan tersebut diperoleh dengan mempergunakan metode adalah sah untuk disebut keilmuan. Karena itu, kegiatan ilmu sesungguhnya bersifat dinamis menembus ruang dan waktu serta mengikuti perkembangan empirik. ${ }^{33}$

Orang bisa membahas suatu kejadian sehari-hari secara keilmuan asalkan dalam proses pengkajian masalah tersebut dapat dipenuhi persyaratan yang telah digariskan. Sebaliknya tidak semua yang diasosiasikan dengan eksistensi ilmu adalah keilmuan. Seorang sarjana yang mempunyai profesi bidang ilmu belum tentu mendekati masalah ilmunya dengan menggunakan prosedur keilmuan. Hakekat ilmu tidak berhubungan dengan titel kesarjanaan, profesi dan kedudukan. Sebaliknya, hakekat keilmuan ditentukan oleh cara berpikir yang dilakukan menurut persyaratan dan prosedur yang ditetapkan. Karena itu ilmu tidak bisa ditempatkan pada suatu struktur feodalisme yang terselubung. Sebaliknya, ilmu bersifat terbuka, demokratis dan menjunjung kebenaran di atas segala-galanya. ${ }^{34}$

Dari segi perkembangannya, ilmu merupakan gabungan dari caracara manusia sebelumnya dalam mencari pengetahuan. Pada dasarnya, ditinjau dari sejarah cara berpikir manusia terdapat dua pola dalam upaya memperoleh pengetahuan. Pertama, berpikir secara rasional dengan menganggap kebenaran sesungguhnya telah ada sejak sedia kala. Pikiran manusia dapat mengetahui ide tersebut namun tidak menciptakannya dan tidak pula mempelajarinya lewat pengalaman. Dengan ungkapan lain, ide tentang kebenaran yang menjadi dasar bagi pengetahuan diperoleh lewat berpikir secara rasional, terlepas dari pengalaman manusia. Sistem pengetahuan dibangun secara koheren di atas landasan-landasan pernyataan yang sudah pasti. ${ }^{35}$

Yang kemudian mengundang pertanyaan, dari manakah kita mendapatkan kebenaran yang sudah pasti manakala ia tercerai dari pengalaman manusia yang nyata? Di sinilah kaum rasionalis mulai mendapatkan kesulitan untuk mendapatkan konsensus yang dapat dijadikan landasan bagi kegiatan berpikir bersama. Tiap orang cenderung untuk percaya kepada kebenaran yang pasti menurut mereka sendiri. Lalu bagaimana kita bisa sampai pada suatu konsensus bila hanya berdasarkan

\footnotetext{
${ }^{33}$ Ibid, hlm. 9

34 Ibid

35 Ibid, hlm. 10
}

30 JURNAL LISAN AL-HAL 
pada penilaian benar secara sepihak. ${ }^{36}$

Dari kesulitan ini lalu muncul pola berpikir lain yang berlawanan dengan rasionalisme, yaitu empirisme yang melandaskan ilmu pada faktor pengalaman manusia. Pengalaman sehari-hari menunjukkan dengan jelas betapa sulitnya kita sampai pada suatu kesimpulan yang disetujui bersama bila hanya berdasarkan pada rasio dan terlepas dari konteks pengalaman manusia sehari-hari. Untuk menghindari debat tidak berkesudahan, kaum empiris menganjurkan agar kita kembali ke alam nyata untuk mendapatkan pengetahuan. Menurut mereka, pengetahuan tidak ada secara apriori di benak kita, melainkan harus diperoleh dari pengalaman. Kegelisahan akademik seperti inilah yang kemudian melahirkan pola pikir empirisme yang semula berasal dari sarjana-sarjana Muslim dan kemudian terkenal di dunia barat lewat tulisan Francis Bacon (1561 - 1626) dalam bukunya Novum Organum yang terbit pada tahun 1620. Sebelumnya, pola pikir rasionalisme juga berasal dari sarjanasarjana Muslim sebelum kemudian mewarnai khazanah keilmuan di dunia barat. Pada mulanya, madzhab ini lahir lewat pembahasan para Filsuf Muslim terhadap filsafat Yunani yang dilakukan antara lain oleh al-Kindi (809 - 873), al-Farabi (881 - 961), Ibnu Sina (980 - 1037), dan Ibnu Rusyd (1126 - 1198). ${ }^{37}$

Selain ahli filsafat, mereka juga pakar di bidang keilmuan. Bahkan, filsafat Ibnu Rusyd mempunyai pengaruh cukup besar terhadap pengembangan ilmu dan pemikiran di barat. pemikiran Ibnu Rusyd kemudian dikenal di dunia barat dengan sebutan Averoisme (Rusydiyyah). Sarjana Islam juga menyumbang kemajuan ilmu dengan pengembangan aljabar oleh al-Khawarizmi, goniometri oleh al-Battani, astronomi dan geografi oleh al-Biruni, ilmu optik oleh al-Haitam, serta penggunaan angka desimal sebagaimana kita pergunakan sekarang. Dunia timur juga ikut meletakkan sendi-sendi kemajuan ilmu, seperti India di bidang matematika dan penemuan angka nol, Cina dengan penemuan kompas, mesiu dan mesin cetak. 38

Secara umum, keilmuan ushul fiqh lahir dan tumbuh berkembang hampir bersamaan dengan proses kemunculan aliran rasionalisme dalam pengembangan ilmu. Walaupun dasar dan fondasi ilmu ushul fiqh telah dirumuskaan al-Syafi'i pada abad ke-7 namun epistemologi ushul fiqh

36 Ibid

37 Ibid

38 Juhaya S. Praja, Aliran-aliran Filsafat \& Etika, hlm. 195: Jujun S. Suriasumantri, Ilmu dalam Perspektif, hlm. 11 
mencapai momentum keilmuannya pada era al-Ghazali yang sezaman dengan Ibnu Rusyd pada abad ke-12. Bedanya dengan Ibnu Rusyd yang konsisten dengan pengembangan ilmu dan filsafat, al-Ghazali dapat melampaui filsafat dan juga teologi dengan menembus dunia sufisme sebagai puncak pengembaraannya dalam pencarian hakekat makna kehidupan manusia sebagai hamba Tuhan. Bagi al-Ghazali, tashawuf-lah yang mampu menjadi penjelas awal dan akhir kehidupan ummat manusia.

Dalam karyanya di bidang ushul fiqh, al-Mustashfa min 'Ilm al-ushul, al-Ghazali mampu mengembangkan kaidah istinbath hukum yang dasardasarnya telah diletakkan sebelumnya oleh al-Syafi'i. Pada era al-Ghazali ini ushul fqh menemukan momentumnya menjadi sebuah epistemologi yang memadukan unsur wahyu dan logika dalam bidang penggalian hukum. Jika pada era al-Syafi'i ushul fiqh mampu menawarkan penyelesaian akademik menyangkut rumitnya perdebatan antara kalanagan ahl al-ra'yi dan ahl al-hadith, maka pada era al-Ghazali ushul fiqh mulai diartikulasi ke dalam banyak monografi sehingga bisa diakses lebih luas oleh masyarakat. Maraknya penyusunan buku ushul fiqh di kalangan madzhab Mutakallimin hingga saat ini hampir bisa dipastikan merujuk kepada karya al-Ghazali al-Mustashfa selain dua kitab induk lainnya, yaitu al-Burhan fi Ushul al-Fiqh karya Imam al-Haramain dan alMu'tamad fi Ushul al-Fiqh karya Imam Abu al-Husain al-Bashri.

\section{Dasar Aksiologi Ilmu}

Pada prinsipnya, ilmu bersifat netral, tidak mengenal sifat baik dan buruk. Apakah ilmu bernilai sebuah keberkatan atau sebaliknya, yakni bermuara pada malapetaka, semuanya bergantung pada siapa yang mengendalikan dan menggunakannya. Dalam bentangan sejarah, ilmu telah banyak berperan dan mengubah wajah dunia. Mulai dari memberantas aneka ragam penyakit, kelaparan, kemiskinan, hingga mengantarkan ummat manusia menuju kejayaan teknologi dan mempermudah komunikasi sehingga dunia yang luas ini tak ubahnya sebuah desa saja yang mudah dijangkau sarana komunikasi kapan saja. Tetapi apakah ilmu selalu berimplikasi positif seperti contoh di atas? Jawabannya tentu "tidak" karena berbagai peperangan dan pengeboman yang berpotensi memusnahkan manusia dan cagar alam juga berasal dari ilmu yang dikembangkan manusia. Karena itu sikap ilmuwan sebagai pemilik ilmu sangat menetukan bagaimana ilmu pengetahuan dapat dimanfaatkan untuk menggapai kebajikan secara maksimal.

Dalam konteks ilmu ushul fiqh, nilai kegunaan yang mesti

$32 \mid$ JURNAL LISAN AL-HAL 
diapresiasi adalah bagaimana bisa dirumuskan kaidah-kaidah istinbath sehingga mampu menelorkan hukum-hukum operasional sebagai panduan setiap manusia mukallaf. Dengan ungkapan lain, tujuan ilmu ushul fiqh dibangun adalah untuk melahirkan preskripsi hukum sebagai guide-line bagi kehidupan ummat manusia sehari-hari. Ushul fiqh dan fiqh merupakan dua jenis ilmu yang tidak bisa dipisahkan satu sama lain. Ushul fiqh bertujuan merumuskaan kaidah dan metode istinbath atau prosedur penggalian hukum. Sedangkan fiqh identik dengan diktum-diktum hukum hasil istinbath yang dilakukan para Mujtahid. Satu kesatuan dari fiqh dan ushul fiqh dapat disimplifikasi tujuannya yaitu untuk menebar kemaslahatan dan menekan terjadinya kerusakan.

Secara filosofi, hukum dibangun memang untuk tujuan menatakelola kehidupan individu maupun masyarakat sehingga tercipta pranata sosial yang berprikemanusiaan. Kehadiran hukum bertujuan untuk mengantarkan ummat manusia menuju kehidupannya yang bermashlahah dan berkeadilan. Dalam tradisi pemikiran hukum, tujuan semacam ini dikenal dengan sebutan maqashidus syari'ah, yakni tujuan akhir disyari'atkannya Islam. Dengan tujuan seperti ini maka dalam pembahasan hukum, unsur "manusia" menjadi sangat strategis sebagai sasaran untuk diperhatikan aspek kebahagiaannya baik di dunia maupun di akhirat. Lantaran manusia hidup dalam sebuah ruang komunitas dan lingkungan yang sangat dinamis maka proses pembentukan hukum pun mengalami eskalasi perkembangan cukup pesat, bahkan cenderung berskala sangat progresif.

Teks wahyu sendiri sebagai sumber inspirasi hukum turun bukan dalam ruang yang kosong, melainkan beriringan dengan konteks realitas yang terus berkembang dan bergerak dinamis. Persinggungan teks wahyu dengan realitas masyarakat, dengan demikian, memiliki maknanya tersendiri dalam memunculkan postulat-postulat hukum. Integrasi teks dan konteks ini perlu dielaborasi secara sistematik karena sejatinya hukum tuhan tidak lahir kecuali untuk konteks kesejahteraan dan kemaslahatan ummat manusia sepanjang sejarahnya. Teks dan konteks mempunyai hubungan komplementer dalam proses pergulatan pencarian wujud kemaslahatan dan kesejahteraan ummat manusia sebagai ending atau tujuan akhir dari seluruh rangkaian proses pembentukan hukum.

Beragam madzhab pemikiran hukum tentunya mempunyai persepsi relatif sebangun menyangkut tujuan akhir pembentukan hukum. Namun, percikan diferensiasi pendapat sering mengemuka lantaran mereka tidak sama dalam melihat pola hubungan antara hukum itu sendiri dengan manusia sebagai subjeknya. Sebagian kalangan berpandangan 
bahwa hukum bukanlah institusi yang absolut dan final melainkan bergantung pada manusia sebagai user. Dalam konteks ini, hukum sangat ditentukan oleh pertanyaan bagaimana manusia melihat dan menggunakannya. Pada kenyataannya, beragam teori hukum yang berkembang selama ini bertumpu kepada kedua faktor ini, hukum dan manusia.

Oleh itu, jika bandul sebuah teori hukum bergeser ke arah manusia maka teori tersebut memberikan ruang cukup banyak pada faktor manusia. Sebaliknya jika bandul teori tadi banyak bergeser ke arah hukum maka teori tersebut akan menganggap hukum sebagai sesuatu yang mutlak, otonom dan final. Pengutuban kedua teori hukum ini pada gilirannya sangat berimplikasi pada lahirnya sejumlah aliran hukum dengan berbagai jenis dan karakternya, mulai dari yang normatiftradisionalis, empiris-positivistik sampai aliran hukum yang bercorak liberal-rasionalis.

\section{B. Kesimpulan}

Sebagai sebuah perangkat metodologi istinbath hukum, ushul fiqh dapat dikaji dengan menggunakan perspektif ilmu pengetahuan. Dimensi keilmuan ushul fiqh dapat ditelusuri menggunakan tahapan ontologi, epistemologi dan aksiologi.

Secara ontologi, ushul fiqh sebagai sebuah metodologi sangat berkaitan dengan fiqh sebagai materi atau substansi. Permulaan wujud fiqh masih diperdebatkan di kalangan para Juris, apakah ia sudah ada sebelum para Juris atau Mujtahid melakukan kerja istinbath al-ahkan (penggalian huku). Untuk menggali ketentuan hukum yang dibutuhkan perlu perangkat metode dan prosedur yang dibenarkan dalam perspektif ilmu pengetahuan. Untuk menjawab pertanyaan inilah kemudian ilmu ushul fiqh hadir sebagai sebuah metodologi hukum yang diupayakan dapat bekerjaa meng-update setiap ketentuan hukum sesuai konteksnya.

Dari aspek epistemologi, ushul fiqh merupakan teori ilmu yang memvokuskan pada kerja penggalian hukum berdasar dalil-dalilnya. Menariknya, sebagai sebuah teori hukum, ushul fiqh memadukan unsur wahyu dan logika secara terintegrasi dalam merumuskan metode dan prosedur istinbath al-ahkam. Ilmu ushul fiqh bukan lahir di ruang yang kosong, melainkan hadir sesuai tantangan dan kebutuhan hukum yang mengemuka. Dengan unsur logika yang dominan di dalamnya, ushul fiqh tidak mudah lekang dengan waktu untuk mengapdate setiap kebutuhan masyarakat di bidang hukum.

34 JURNAL LISAN AL-HAL 
Dari sudut aksiologi, ilmu ushul fiqh dibangun untuk merumuskan kaidah-kaidah istinbath sehingga mampu melahirkan preskripsi hukum sebagai guide-line bagi kehidupan ummat manusia sehari-hari. Ushul fiqh dan fiqh merupakan dua jenis ilmu yang tidak bisa dipisahkan satu sama lain. Ushul fiqh merupakan metodologi hukum yang bertujuan untuk merumuskan prosedur penggalian hukum dengan mengacu pada sumbersumbernya baik yang bersifat naqli berupa teks wahyu maupun 'aqli berupa perengakat logika dan penalaran ilmiah. Sedangkan fiqh identik dengan diktum-diktum hukum hasil istinbath yang dilakukan para Mujtahid. Satu kesatuan dari fiqh dan ushul fiqh ini dapat disimplifikasi muaranya untuk menebar kemaslahatan dan menekan terjadinya kerusakan. Kehadiran hukum yang digali menggunakan perangkat ilmu ushul fiqh tak lain mempunyai tujuan mengantarkan ummat manusia menuju kehidupannya yang bermartabat, bermashlahah dan berkeadilan. 


\section{Daftar Pustaka}

Abu Zayd, Nashr Hamid, Prof. Dr., Mafhum al-Nash: dirasah fi Ulum alQur'an. Kairo: al-Hai'ah al-Mishriyyah al-'Ammah Li al-Kitab, 1993.

Ba'albaki (al-), Rohi, Dr., al-Mawrid Qamus 'Arabi-Inglizi. Beirut: Dar al'Ilm li al-Malayin, 1997.

Ghazali (al-), Abu Hamid Muhammad bin Muhammad, al-Mustashfa Min 'Ilm al-Ushul. Beirut: Dar al-Fikr, tt.

Jabiri (al-), Muhammad 'Abid, Dr., Bunyah al-'Aql al-'Arabi: Dirasah Tahliliyyah Naqdiyyah li Nudhum al-Ma'rifah fi al-Thaqafah al'Arabiyyah. Beirut: al-Markaz al-Thaqafi al-'Arabi, 1993.

Praja, Juhaya S., Prof. Dr. Aliran-aliran Filsafat \& Etika. Jakarta: Prenada Media, 2003.

Suriasumantri, Jujun S., Ilmu dalam Perspektif: Sebuah Kumpulan Karangan tentang Hakekat Ilmu. Jakarta: Yayasan Obor Indonesia, 2009.

Syafi'i (al-), Muhammad bin Idris, al-Risalah (Tahqiq wa syarh Ahmad Muhammad Syakir). Beirut: Dar al-Fikr, tt.

Uways, Abdul Halim, Dr., al-Fiqh al-Islami Bayna al-Tathawwur wa alThabat, dalam edisi Indonesia, Fiqh Statis-Dinamis. Bandung: Pustaka Hidayah, 1998.

36 JURNAL LISAN AL-HAL 
